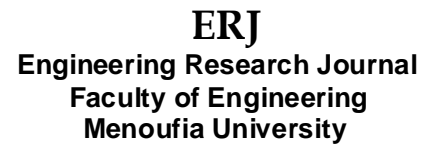

\title{
Optimal Allocation of multiple Distribution Generations in Radial distribution systems using Different Optimization Techniques
}

\author{
Shimaa Mohamed Ali, \\ Faculty of Energy Engineering \\ Aswan University, Egypt \\ shimaat.ali@aswu.edu.eg
}

\author{
Al-Attar Ali Mohamed, \\ Faculty of Engineering \\ Aswan University, Egypt \\ attar@aswu.edu.eg
}

\author{
Ashraf Mohamed Hemeida, \\ Faculty of Energy Engineering \\ Aswan University, Egypt \\ ahemeida@yahoo.ca
}

\author{
Abdalla Ahmed Ibrahim \\ Faculty of Engineering \\ Aswan University, Egypt \\ Abdalla.Ibrahim@eng \\ aswu.edu.eg
}

\begin{abstract}
:
This paper presents, Ant Lion Optimizer (ALO), Flower Pollination algorithm (FPA), Whale Optimization Algorithm (WOA), Satin Bowerbird Algorithm (SBO) and Moth Swarm Optimization(MSA) for determining the optimal location and sizing of DGs to minimize power losses in radial distribution networks(RDN) and improve the voltage profile. DGs operating at different power factors are considered that is (unity and optimal). The maintenance, operation and investment costs are formulated to form the total costs of DGs and also all the profits that DG Owner's (DGOs) are considered at the same time. The proposed methods are implemented on IEEE 33, 69 and 119-bus test systems and the obtained results of the proposed methods are compared with other popular methods available in the literature for validation purpose.

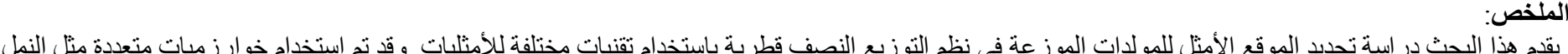

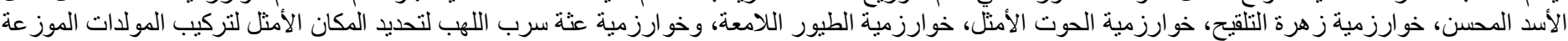

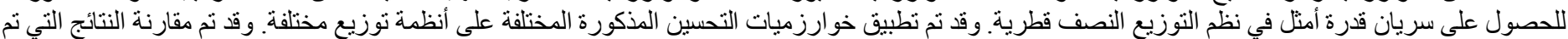
الحصول عليها من خو ارزميات التحسين المختلفة.
\end{abstract}

Keywords : Optimization Algorithm, distributed generation, Radial Distribution system, power losses reduction.

\section{INTRODUCTION}

Optimization techniques have become more popular in the last two decades, and extended to cover different areas of study. Genetic algorithms (GA), Ant colony optimization (ACO), and particle swarms optimization (PSO) are the most well-known techniques from meta-heuristic optimization techniques. These techniques are the most used optimization techniques due to their simplicity, flexibility, derivation free mechanism, and local optima avoidance. The meta-heuristic optimization techniques have different advantages makes them the first choice for solving optimization problems. Their simplicity comes from being reveal of natural phenomena, animals behaviors, or evolutionary concepts. Moreover, they can be applying simply to different optimization problems without any change in algorithm structure, and they are the most suitable optimization techniques for real problems. Different modification techniques have been introduced to enhance the performance of (PSO) [1].

In recent years, the penetration of distributed generator (DG) into distribution systems has been increasing rapidly in many parts of the world. The main reasons for the increase in penetration are the liberalization of electricity markets, constraints on building new transmission and distribution lines, and environmental concerns [2]-[3]. Technological advances in small generators, power electronics, and energy storage devices for transient backup have also accelerated the penetration of DG into electric power generation plants [4]. At present, there are several technologies used for DG applications that range from traditional to nontraditional technologies. The former is nonrenewable technologies such as internal combustion engines, combined cycles, combustion turbines, and micro turbines. The latter is renewable technologies such as solar, photovoltaic, wind, geothermal, ocean, and fuel cell. The main advantages of using renewable-energy-based DG sources are the elimination of harmful emissions and inexhaustible resources of the primary energy. However, the main disadvantages are relative low efficiency, high costs, and intermittency [5], [6]. Grey wolf optimizer (GWO)is used to minimized load buses voltage deviations and system power losses[7].novel Moth Swarm Algorithm (MSA), used to solve constrained Optimal Power Flow (OPF) problem[8].

The present work is aimed to develop Ant Lion Optimizer (ALO), Flower Pollination algorithm (FPA), Whale Optimization Algorithm (WOA), Satin Bowerbird Algorithm (SBO) and Moth Swarm Optimization (MSA) to find the optimal sizing and locations of the DGs for power losses minimization and to enhance bus voltages profile in radial distribution network. The maintenance, operation and investment costs are formulated to form the total costs of DGs and also all the profits that DGOs are considered at the same time. The simulation work carried on 33-bus, 69-bus and 119bus radial distribution systems and the effectiveness of the 
proposed algorithms are validated with the other optimization methods.

In this paper, different test scenarios are considered with an aim to quantify the benefits for distribution networks with the optimal placement of DG units with real power injection (Type-I DG units) as well as real and reactive power injection capabilities (Type-III DG units).

\section{PROBLEM Formulation}

One advantage of deploying a DG-unit in distribution networks is to minimize the total system real power loss while satisfying certain operating constraints. In other words, the problem of DG-unit application can be interpreted as finding the optimal sizing and locations of those DG-units to satisfy the desired objective function subject to equality and inequality constraints. Reliability, accuracy, and flexibility of the DG-unit solution are obtained. Therefore, the overall algorithm accuracy is highly reliant on that analysis. It can be said that, the powerflow analysis is the heart of the DG-units solution algorithm.

\section{A. Objective Functions}

\section{A.1. Total active power losses}

The radial distribution networks include series impedances to represent the distribution lines, balanced power sinks and constant power loads to form a symmetrical network. The simplified recursive Eqs (1)-(3) are used to get the load flow solution in the RDN. The active and reactive power flows at the terminal node of $i+1$ th branch can be mathematically stated as [9]:

$P_{i+1}=\left[P_{i, i+1}-\left(R_{i, i+1} \frac{P_{i, i+1}^{2}+Q_{i, i+1}^{2}}{\left|V_{i}\right|^{2}}\right)-P_{i+1}^{L}+\alpha_{P D G} P_{i+1}^{D G}\right]$

$Q_{i+1}=$

$\left[Q_{i, i+1}-\left(R_{i, i+1} \frac{P_{i, i+1}^{2}+Q_{i, i+1}^{2}}{\left|V_{i}\right|^{2}}\right)-Q_{i+1}^{L}+\right.$

$\left.\alpha_{q D G} Q_{i+1}^{D G}\right]$

$\left|V_{i+1}\right|^{2}=$

$\left[\left|V_{i}^{2}\right|+\frac{R_{i, i+1}^{2}+X_{i, i+1}^{2}}{\left|V_{i}\right|^{2}}\left(P_{i, i+1}^{2}+Q_{i, i+1}^{2}\right)-2\left(R_{i, i+1} P_{i, i+1}+\right.\right.$

$\left.\left.X_{i, i+1} Q_{i, i+1}\right)\right] \quad i=1,2, ., n$

Where $P_{i+1}$ is real power flows out of node $i+1, Q_{i+1}$ is reactive power flows out of node $i+1, R_{i, i+1}$ is resistance of line between nodes $i$ and $i+1, X_{i, i+1}$ is reactance of line between nodes $i$ and $i+1, P_{i, i+1}$ is active power flows out of node $i$ to node $\mathrm{i}+1, \mathrm{Q}_{\mathrm{i} i \mathrm{i}+1}$ is reactive power flows out of node $\mathrm{i}$ to node $\mathrm{i}+1, \mathrm{P}^{\mathrm{L}}{ }_{\mathrm{i}+1}$ is real power load demand at node $i+1, Q^{L}{ }_{i+1}$ is reactive power load demand at node $i+1, \alpha_{\mathrm{PDG}}$ is active power multiplier which is equal to zero if there is no active power injection source or equal to 1 if any active power injection source (DG unit) is present and $\alpha_{\mathrm{qDG}}$ is reactive power multiplier which is set to zero if there is no reactive power injection or set to 1 if any reactive power injection sources (Type-III DG unit) are present.

Current flows through the branch between the nodes $i$ and $\mathrm{i}+1$ is computed as [9]

$I_{i, i+1}=\sqrt{\frac{P_{i, i+1}^{2}+Q_{i, i+1}^{2}}{\left|V_{i}\right|^{2}}}$

Where $I_{i, i+1}$ is current flows between the nodes $i$ and $i+1$.

Power loss associated with the branch between the nodes $i$ and i+1 may be computed as [9]

$P_{\text {lossi }, i+1}=\left|I_{i, i+1}\right|^{2} R_{i, i+1}$

The summation of power losses related with the real and reactive part of branch current magnitude in all the branches of the RDN as indicated in Eq. (6).

$P_{\text {loss } T}=\left[\left|I_{P(i, i+1)}\right|^{2} R_{i, i+1}+\left|I_{q(i, i+1)}\right|^{2} R_{i, i+1}\right]$

Where $\mathrm{P}_{\text {lossT }}$ total power loss in the RDN without DG's

This study aims to minimize the real power loss by reducing the real and reactive currents by injecting real and reactive power with the aid of DG units of suitable ratings placed at appropriate locations. Power loss lays between the nodes $i$ and $i+1$ after the placement of DG units is computed as,

$P_{\text {loss }(i, i+1)}^{D G}=\left[\left(R_{i, i+1} \frac{\left(P_{i, i+1}-\alpha_{P D G} P_{i+1}^{D G}\right)^{2}+\left(Q_{i, i+1}-\alpha_{q D G} Q_{i+1}^{D G}\right)^{2}}{\left|V_{i}\right|^{2}}\right)\right]$

Total power loss of RDN after compensation with DG is computed as,

$P_{\text {lossT }}^{D G}=\left[\sum_{\mathrm{i}=1}^{\mathrm{nb}} P_{\text {loss }(i, i+1)}^{D G}\right]$

Where $\mathrm{n}_{\mathrm{b}}$ is total number of branches in the RDN, $\mathrm{P}^{\mathrm{DG}}{ }_{\operatorname{loss}(\mathrm{i}, \mathrm{i}}$ +1 is real power loss in the branch connected between nodes and $\mathrm{i}+1$ with DG's and $\mathrm{P}_{\text {lossT }}^{\mathrm{DG}}$ is total power loss in the RDN with DG units.

The objective functions for finding the appropriate locations, sizes of the DGs to minimize the total power loss of RDN and improve the voltage profile are expressed as

$$
\begin{array}{r}
\text { Obf }=\mathrm{F} 1=\text { Minimize }\left(\mathrm{P}_{\text {loss } \mathrm{T}}\right) \\
\mathrm{V}_{\text {Profile }}=\sum_{\mathrm{ni}=1}^{\mathrm{n}_{\mathrm{n}}}\left(\mathrm{V}_{\mathrm{ni}}-\mathrm{V}_{\text {rated }}\right)^{2}
\end{array}
$$


Where $n_{n}$ is the total number of the bus, $V_{n i}$ and $V_{\text {rated }}$ are the minimum voltage at bus $\mathrm{n}_{\mathrm{i}}$ and rated voltage (1 p.u.) respectively A.3. DG Owner's Cost and Profit Functions

To modeling cost and profit functions, the optimization methods must be applied to find the optimum value of the planning parameters for the DG's sizes, locations and the electricity contract price between the DG owner and the DisCo. So that the following cost and profit functions can be defined for the DG owner as follows [10]:

A.3.1. Investment Cost: This cost contains the different initial costs, such as the amount of money spent on unit construction, installation, and essential equipments. For each unit of generation, this cost can be formulated as the following equation:

$C_{\text {Investment }}=\sum_{i=1}^{N_{D G}} P_{D G, i} \times$ Cost $_{\text {Investment }}$

Where $\mathrm{i}$ denotes the distributed generation index, $\mathrm{P}_{\mathrm{DG}, \mathrm{i}}$ denotes the active power generated by the $\mathrm{i}$ the unit, $C_{\text {Investment }}$ denotes investment cost of DGs (U.S. $\$$ MW) $=318000 . \$ / M W$.

A.3.2. Operational Cost: Costs of fuel, generation, and other similar ones can be combined together as the operational cost. The equation for modeling the present worth of this cost is as follow:

$\mathrm{C}_{\text {operational }}=$

$\sum_{\mathrm{j}=1}^{\mathrm{N}_{\mathrm{Y}}} \sum_{\mathrm{i}=1}^{\mathrm{N}_{\mathrm{DG}}} \mathrm{P}_{\mathrm{DG}, \mathrm{i}} \times \mathrm{CF}_{\mathrm{i}} \times \mathrm{T}_{\mathrm{h}} \times$ Cost $_{\text {operational }} \times$

$\left(\frac{1+\text { INF_R }}{1+\text { INT_R }}\right)^{\mathrm{j}}$

Where, $\mathrm{j}$ denotes the year index, $\mathrm{C}_{\text {operational }}$ denotes operational cost of DGs (U.S. $\$$ MW) $=29$. $\$$ MW [ 10].

A.3.3. Maintenance Cost: This term includes costs of renewing, repairing, and restoring unit equipment in case of necessity. The present worth of this cost can be formulated as follow:

$\mathrm{C}_{\text {maintenance }}=\sum_{\mathrm{j}=1}^{\mathrm{NY}} \sum_{\mathrm{i}=1}^{\mathrm{N}_{\mathrm{DG}}} \mathrm{P}_{\mathrm{DG}, \mathrm{i}} \times \mathrm{CF}_{\mathrm{i}} \times \mathrm{T}_{\mathrm{h}} \times$ Cost $_{\text {maint }} \times$ $\left(\frac{1+\text { INF_R }}{1+\text { INT_R }}\right)^{\mathrm{j}}$

Where, $\mathrm{C}_{\text {maintenance }}$ denotes maintenance cost of DGs (U.S. $\$ / M W)=7 . \$ / M W[10]$.

A.3.4 DG Owner's Income: The DG owner gains profit from selling generated power to the DisCo based on the contract price. The present worth of the DG owner's income is:

$$
\begin{aligned}
& \mathrm{IN}_{\mathrm{DG}}=\sum_{\mathrm{j}=1}^{\mathrm{N}_{\mathrm{Y}}} \sum_{\mathrm{i}=1}^{\mathrm{N}_{\mathrm{DG}}} \mathrm{P}_{\mathrm{DG}, \mathrm{i}} \times \mathrm{CF}_{\mathrm{i}} \times \mathrm{T}_{\mathrm{h}} \times \mathrm{CP}_{\mathrm{DG}} \times \\
& \left(\frac{1+\mathrm{INF}_{\mathrm{R}}}{1+\mathrm{INT}_{\mathrm{R}}}\right)^{\mathrm{j}}
\end{aligned}
$$

Where, $\mathrm{CP}_{\mathrm{DG}}$ denotes Contract price of selling DG power between the DG owner and the DisCo (U.S.\$MWh), CF denotes capacity factor of DG units $=1, \mathrm{~T}_{\mathrm{h}}$ denotes Total number of hours in a year (in hours). It is assumed that the interest rate and the inflation rate are $12.5 \%$ and $9 \%$, respectively[10]. .

\section{B. Constraints}

Constraints and Limitations: This optimization problem is subjected to various constraints as follows.

B.1. Generation constraints: For stable operation, real power outputs and reactive power outputs are restricted by the lower and upper limits as follows [11]:

$$
\begin{aligned}
& P_{G i}^{\min } \leq P_{G i} \leq P_{G i}^{\max } \\
& \mathrm{Q}_{\mathrm{Gi}}^{\min } \leq \mathrm{Q}_{\mathrm{Gi}} \leq \mathrm{Q}_{\mathrm{Gi}}^{\max }
\end{aligned}
$$

Where, $P_{G i}, \mathrm{Q}_{\mathrm{Gi}}$ are active and reactive generated power of bus $\mathrm{i}$ , $P_{G i}^{\min }, \mathrm{Q}_{G \mathrm{i}}^{\min }$ are the minimum active and reactive generated power of bus $\mathrm{i}$ and $P_{G i}^{\max }, \mathrm{Q}_{\mathrm{Gi}}^{\max }$ are maximum active and reactive generated power of bus $i$.

B.2. Bus Voltages Limits: At each node of (RDN), the bus voltage magnitudes should be maintained within the prescribed operating ranges as follows:

$V_{i}^{\min } \leq V_{i} \leq V_{i}^{\max }$

Where $V_{i}^{\min }=0.95 p u$ and $V_{i}^{\max }=1.1 \mathrm{pu}$

In this section, the objective functions and their related constraints for solving this optimization problem are introduced.

\section{PRELIMINARIES OF PROPOSED ALGORITHMS}

\section{A. Ant Lion Optimizer}

The ALO [12] is a metaheuristic algorithm which simulates the interaction between ants and ant-lions in the trap. This algorithm is characterized as a three-tuples function, ALO (A1; A2; A3), that approximates the global optimum for optimization issues. These tuples A1, A2 and A3, are formally defined as follows, respectively:

$\varphi \stackrel{\mathrm{A} 1}{\longrightarrow}\{$ GAnt; GOA; GAntlion; GOAL $\}$

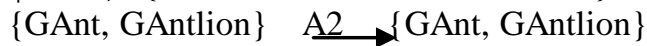

\{GAnt, GAntlion $\stackrel{\mathrm{A} 3}{\longrightarrow}$ true, false\}

Where GAnt is the ants' position matrix, GAntlions contains the ant lions' position, GOA includes fitness of ants, and GOAL has ant lions fitness. In this algorithm the ant lion matrices are randomly initialized utilizing the function A1. The position of each ant with respect to an ant lion is chosen by the roulette wheel operator while the elite is updated by the function A2 in each iteration. The position updating the boundary is first 
characterized relative to the current iteration number. The position is then updated by two random walks around the chosen elite and ant lion. The points, when every ant randomly walks, are estimated by the fitness function. In the event that any of the ants become to be fitter than whatever other ant lions, in the next iteration, their positions are considered as the new positions for the ant lions. The best ant lion is contrasted to the best ant lion obtained while optimization (elite) and replaced in the event that it is fundamental. These steps iterative until the function A3 returns false. The pseudo codes the ALO calculations are characterized as shown in Fig.1:

\begin{tabular}{ll}
\hline & Algorithm A. Ant Lion Optimizer (ALO) \\
\hline 1) & Initialize a population of n ant-lions and ants at random. \\
2) & Compute the ant-lions and ants fitness. \\
3) & Locate the best ant-lions and suppose it is the elite. \\
4) & While the end criterion is not satisfied. \\
& for each ant. \\
& Choose an ant-lion utilizing Roulette wheel. \\
& Generate a random walk and normalize it. \\
& Update the position of ant. \\
& end for \\
Compute the fitness of all ants. & Substitute an ant-lion with its comparing \\
ant if the ant is fitter. \\
Update elite if an ant-lion gets fitter than \\
the elite.
\end{tabular}

Fig .1: Pseudo code of the proposed Ant Lion Optimizer (ALO)

\section{B. Flower Pollination Algorithm (FPA)}

Flower Pollination Algorithm (FPA) was founded by Yang in the year 2012. Inspired by the flow pollination process of flowering plants are the following four steps are used [13]:

Step 1: Global pollination represented in biotic and cross pollination processes, as pollen-carrying pollinators fly following Lévy flight [14].

Step 2: Local pollination represented in a biotic and self pollination as the process does not require any pollinators.

Step 3: Flower constancy which can be developed by insects, which is on a par with a reproduction probability that is proportional to the similarity of two flowers involved.

Step 4: The interaction of local and global pollination is controlled by a switch probability p $\epsilon[0,1]$, lightly biased toward local pollination.

The basic steps of FPA can be summarized as the pseudo codes shown in Fig. 2

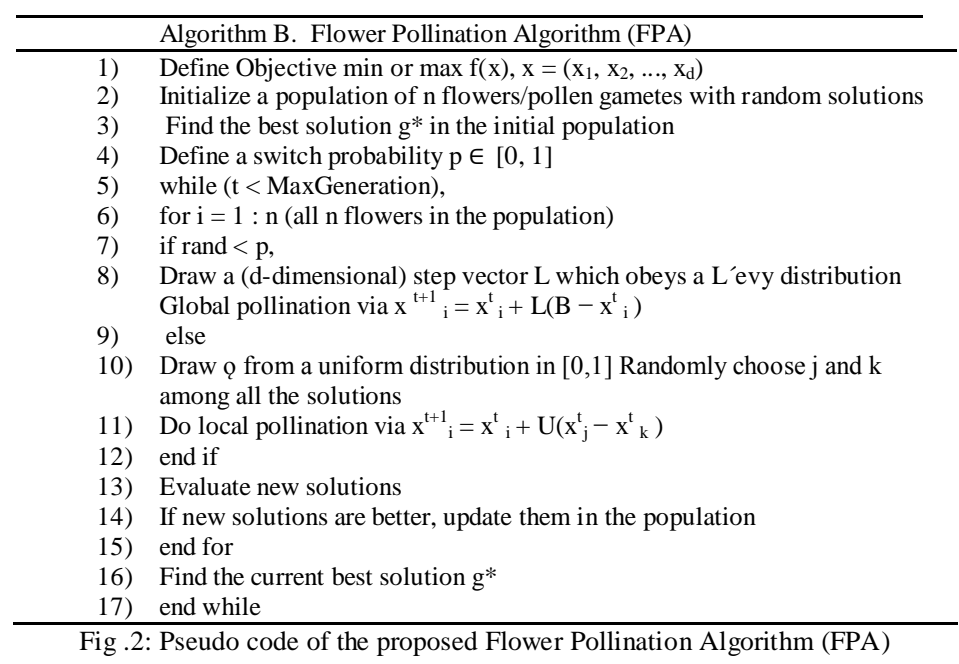

\section{Whale Optimization Algorithm}

The Whale optimization algorithm [15] is a newly proposed meta-heuristic that is inspired from the bubble-net hunting technique of humpback whales. The WOA describes the special pursuing behavior of humpback whales, in which the whales attempt to encircle the prey (fish herds) near the surface of the water while creating bubbles that are in the shape of a circle. In the bubble-net hunting technique, the humpback whales dive approximately 12 meters down and then begin to make bubbles in a spiral shape around the prey and swim toward the surface. The general steps of the Whale optimization algorithm (WOA) can be summarized in the pseudo code as shown in Fig.3

Algorithm C. Whale optimization algorithm (WOA)

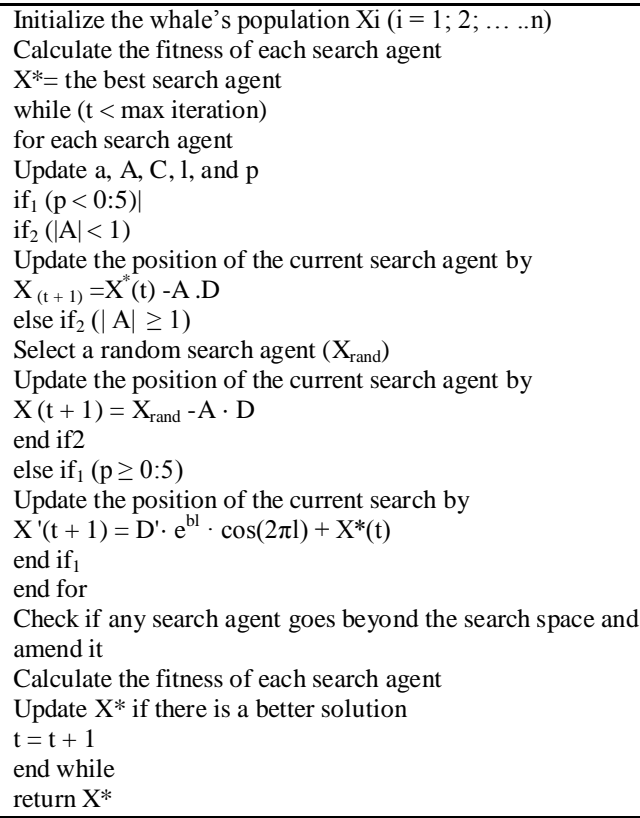

Fig .3: Pseudo code of the proposed Whale optimization algorithm (WOA) 


\section{Satin Bowerbird Optimization Algorithm}

The satin bowerbird optimization algorithm [16] comes from the concept of behavior and process of choosing the female birds for mating from Eastern Australia. During autumn and winter season, satin bowerbirds leave their forest habitat and move woodlands to forage for fruit and insects. In the mating season, for attracting the female birds it (male bowerbirds) build specialized stick structures, called bowers, where courtship and copulation take place. Bowers are made and decorated by flowers, feathers, berries etc. These decorations are necessary for female birds to choose male bird for male mating success. Males compete with other male birds by stealing decoration materials and try to destroy the bowers of their neighbors. Male courtship behavior includes presentation of decorations and dancing displays with loud vocalizations, and females prefer males that display at high intensity. Another indication of strong mating competition is that not all adult males are successful at constructing, maintaining and defending bowers, and as a result, there is considerable variability in male mating success. In simple terms, male bowerbirds attract mates by constructing a bower, a structure built from sticks and twigs, and decorating the surrounding area. Females visit several bowers before choosing a mating partner and returning to his bower after mating.

The general steps of the satin bowerbird optimization algorithm (SBO) can be summarized in the pseudo code as shown in Fig.4

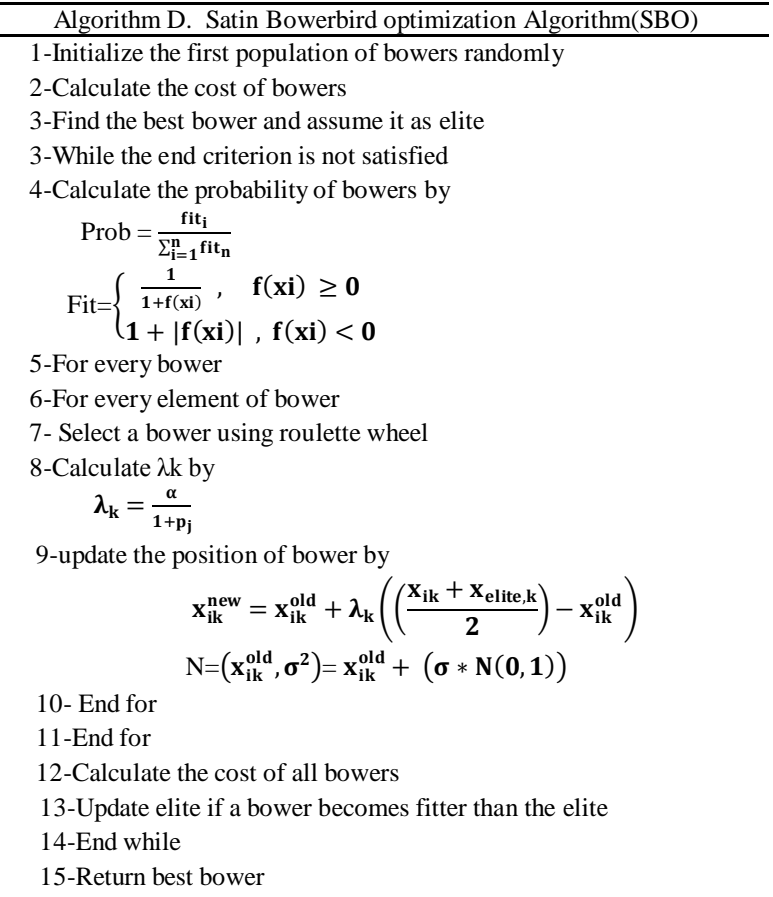

Fig .4: Pseudo code of the Satin Bowerbird optimization Algorithm (SBO)

\section{E. Moth Swarm Optimization}

Moth Swarm Optimization (MSA) is inspired by the orientation of moths towards moonlight for presenting optimal location and sizing of DG on distribution systems [17]. The fitness function of this solution is considered as luminescence intensity of the light source. The proposed moth swarm is considered to have three types of moth they are classified as follows:

Pathfinders: with the principle of First in last out the small group of moth are able to find the new areas over the optimization space. It mainly involves in guiding the main swarm by discriminating the best positions of light source.

Prospectors: These are the group of moth that wanders in random spiral path which is indicated by pathfinders within the neighborhood light source area.

Onlookers: These are the group of moth that directly moves towards the best global position (moonlight) that has been obtained by prospectors.

\begin{tabular}{|c|}
\hline Algorithm E. Moth Swarm Optimization Algorithm(MSA) \\
\hline $\begin{array}{l}\text { Initialize the moth swarm population. } \\
\text { Calculate the swarm finesses \& identify the type of each moth }\end{array}$ \\
\hline $\begin{array}{c}\text { while } \mathrm{t}<\max \text { number of iteration } \mathrm{T} \text { for each light source, } \\
\text { Identify the crossover points } \mathrm{cp} \mathrm{c}\{\mathrm{c} 1, \mathrm{c} 2, \ldots, \mathrm{cnc}\} \\
\text { Generate Lếvy-flights samples } \mathrm{L}_{\mathrm{p}} \\
\text { Create/ mutate sub-trail vector } \mathbf{v}_{\mathbf{p}}^{\mathrm{t}} \\
\text { Construct the completed trail solution } \mathbf{V}_{\mathbf{p}}^{\mathbf{t}} \\
\text { Select the artificial light sources } \mathbf{x}_{\mathbf{p}}^{\mathbf{t + 1}} \\
\text { End for reconnaissance. } \\
\text { Calculate the probability values } \mathrm{P}\end{array}$ \\
\hline $\begin{array}{l}\text { For each prospector moth, xi is } \\
\text { update the position of prospector moth } \\
\text { Calculate the finesses of prospector } \\
\text { End for Transverse orientation. } \\
\text { Defined the new light sources and moonlight. }\end{array}$ \\
\hline $\begin{array}{l}\text { For each onlooker moth (worse group), } \\
\text { Update the position according to its type. } \\
\left.\text { If ( } \mathrm{i} \in \mathrm{n}_{\mathrm{G}}\right) \text {. } \\
\text { Generate Gaussian walks steps } \boldsymbol{\varepsilon}_{1}, \boldsymbol{\varepsilon}_{2} \text {, and } \boldsymbol{\varepsilon}_{3} \\
\text { Move the onlooker position with Gaussian walks } \mathbf{x}_{\mathrm{i}}^{\mathrm{t}+\mathbf{1}} \\
\text { Else, } \\
\text { Drift the onlooker moth using the associative learning operators with } \\
\text { immediate memory. } \\
\text { End if. } \\
\text { Calculate the finesses of onlooker moth } \\
\text { End for Celestial navigation. }\end{array}$ \\
\hline $\begin{array}{c}\text { Identify the new light sources and moonlight, and type of each moth. } \\
\text { End while } \\
\text { Print global best solution (moonlight) }\end{array}$ \\
\hline
\end{tabular}

Fig .5: Pseudo code of the Moth Swarm Optimization Algorithm (MSA) 


\section{CASE STUDY, RESULTS, AND DISCUSSION}

To demonstrate the effectiveness of the pervious algorithms, comparative analyses are made with other optimization methods. The strategy envisages examining the veracity of those optimization algorithms using 33-bus, 69-bus and 119-bus test systems on a Matlab platform. The maximum number of iterations is set to 100 for all systems. In this paper, the following two scenarios are taken into consideration as.

Scenario I: Type-I DG units capable of injecting active power only (unity p.f) are installed at potential nodes.

Scenario II: Type-III DG units capable of injecting .both real and reactive powers are installed at potential nodes. Case Study

\section{A.1. Test case1: 33- bus test system}

To demonstrate the effectiveness of the pervious methods, it is applied on small scale distribution network. It is a balanced three phase radial network consists of 33 nodes with 32 segments with $12.66 \mathrm{kV}$ as operating voltage level and total real and reactive power load demands of the system are $3720 \mathrm{~kW}$ and 2300 KVAR respectively. Before the placement of DG units the total active and reactive power losses are $202.7 \mathrm{~kW}$ and 140.03 KVAR, respectively. The test system data such as line and load data are obtained from [9].

\section{Scenario-I:}

In scenario-I, Type-I DG units capable of injecting active power only is installed at potential nodes. The optimal DG sizes, locations, power loss, the voltage profile and the minimum voltage magnitude with and without placement of DG are tabulated in Table 1. It is noticed that power loss is reduced effectively and voltage profile values are improved effectively with placement of DGs. The results of those approaches are compared with other optimization methods and achieved better solutions than [19] and GA [20].

The Investment Cost, Operational Cost, Maintenance Cost, total costs and DG Owner's Income are tabulated in Table 2 for DGs operating at unity power factor.

\section{Scenario II:}

The methods continuous to investigate the performance of the test system with the placement of Type-III DG units where capable of injecting both real and reactive powers operating at 0.866 power factor. The obtained results are tabulated in Tables 3. From Table 3, it is clearly observed that the power loss of the optimization methods is reduced effectively compared to the BFOA method, and FA [21].

Fig.7 shows the performance of the optimization methods. It is clear that the methods are more efficient in finding out the optimal allocation of DGs with reducing the power loss and improving voltage profile.
Table 1 Comparison and performance analysis of 33-bus test system at unity power factor

\begin{tabular}{|c|c|c|c|c|c|c|c|c|}
\hline Method & $\begin{array}{l}\text { Base } \\
\text { Case }\end{array}$ & WOA & FPA & ALO & MSA & SBO & $\begin{array}{c}\text { GA } \\
{[20]}\end{array}$ & [19] \\
\hline $\begin{array}{c}\text { DG } \\
\text { Location }\end{array}$ & - & $\begin{array}{l}30 \\
24 \\
11\end{array}$ & $\begin{array}{l}24 \\
30 \\
15\end{array}$ & $\begin{array}{l}12 \\
30 \\
25\end{array}$ & $\begin{array}{l}12 \\
24 \\
30\end{array}$ & $\begin{array}{l}13 \\
24 \\
30\end{array}$ & $\begin{array}{l}11 \\
29 \\
30\end{array}$ & $\begin{array}{l}14 \\
18 \\
32\end{array}$ \\
\hline $\begin{array}{c}\text { DG } \\
\text { size } \\
(\mathbf{k W})\end{array}$ & - & $\begin{array}{l}913.23 \\
1029.6 \\
1026.9\end{array}$ & $\begin{array}{l}977.52 \\
1016.2 \\
689.03\end{array}$ & $\begin{array}{l}917.11 \\
1039.6 \\
836.57\end{array}$ & $\begin{array}{l}897.25 \\
1073.6 \\
1015.3\end{array}$ & $\begin{array}{l}787.71 \\
1092.1 \\
1059.8\end{array}$ & $\begin{array}{c}1500 \\
422.8 \\
1071.5\end{array}$ & $\begin{array}{c}652.1 \\
198.4 \\
1067.2\end{array}$ \\
\hline $\begin{array}{l}\text { Ploss } \\
(\mathrm{KW})\end{array}$ & 203 & 72.76 & 72.59 & 72.75 & 72.11 & 71.51 & 106.3 & 89.9 \\
\hline $\begin{array}{c}\text { Vmin } \\
\text { (pu) } \\
\text { (bus) }\end{array}$ & $\begin{array}{c}0.913 \\
1 \\
(18)\end{array}$ & $\begin{array}{c}0.9675 \\
(33)\end{array}$ & $\begin{array}{c}0.9651 \\
(33)\end{array}$ & $\begin{array}{c}0.9678 \\
(18)\end{array}$ & $\begin{array}{c}0.9672 \\
(18)\end{array}$ & $\begin{array}{c}0.9681 \\
(33)\end{array}$ & $\begin{array}{c}0.9809 \\
(25)\end{array}$ & $\begin{array}{c}0.9705 \\
(28)\end{array}$ \\
\hline $\begin{array}{l}\text { Voltage } \\
\text { profile }\end{array}$ & $\begin{array}{c}1.701 \\
2\end{array}$ & 0.5902 & 0.6555 & 0.5978 & 0.5934 & 0.586 & NA & NA \\
\hline $\begin{array}{l}\text { Time } \\
\text { (sec) }\end{array}$ & - & 19 & 19.3 & 19.7 & 18.9 & 19.7 & NA & NA \\
\hline
\end{tabular}

Table 2 Economical costs for DG allocation for 33-bus system (Type-I)

\begin{tabular}{|c|c|c|c|c|c|}
\hline Method & WOA & FPA & ALO & MSA & SBO \\
\hline $\begin{array}{c}\text { Investment } \\
\operatorname{Cost}(\$)\end{array}$ & 944382.2 & 853100.2 & 888264.3 & 949607.02 & 934797.7 \\
\hline $\begin{array}{c}\text { Operational } \\
\text { Cost }(\$)\end{array}$ & 730965.3 & 660311.7 & 687529.3 & 735009.3 & 723546.7 \\
\hline $\begin{array}{l}\text { Maintenanc } \\
\text { e } \operatorname{Cost}(\$)\end{array}$ & 176439.9 & 159385.6 & 165955.3 & 177416 & 174649.2 \\
\hline $\begin{array}{c}\text { Total } \\
\operatorname{costs}(\$)\end{array}$ & 1851787 & 1672797 & 1741749 & 1862032 & 1832993 \\
\hline $\begin{array}{l}\text { DG Owner's } \\
\text { Income(\$) }\end{array}$ & 1260285 & 1138468 & 1185395 & 1267257 & 1247494 \\
\hline
\end{tabular}

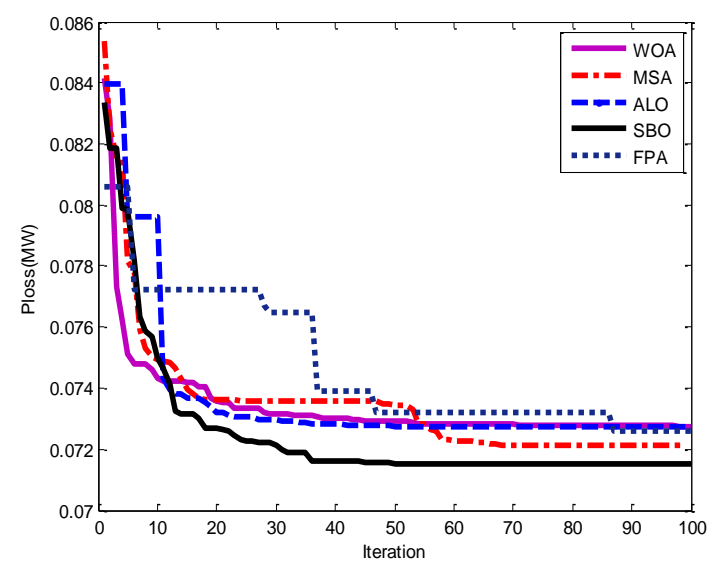

Fig.6 A convergence between the characteristics of objective function for 33-bus system (Type-I) 
The Investment Cost, Operational Cost, Maintenance Cost, total costs and DG Owner's Income are given in Table 4 for DGs operating at 0.866 power factor. It is noticed that the total cost of the WOA algorithm is less than MSA, FBA, ALO and SBO.

Table 3 Comparison and performance analysis of 33 -bus system at 0.866 power factor

\begin{tabular}{|c|c|c|c|c|c|c|c|c|}
\hline Method & $\begin{array}{l}\text { Base } \\
\text { Case } \\
\end{array}$ & WOA & FPA & ALO & MSA & SBO & $\begin{array}{l}\text { BFOA } \\
{[22]}\end{array}$ & FA \\
\hline $\begin{array}{c}\text { DG } \\
\text { Location }\end{array}$ & - & $\begin{array}{r}30 \\
3 \\
10\end{array}$ & $\begin{array}{l}31 \\
25 \\
10\end{array}$ & $\begin{array}{c}3 \\
30 \\
13\end{array}$ & $\begin{array}{l}24 \\
30 \\
10\end{array}$ & $\begin{array}{l}13 \\
30 \\
24\end{array}$ & $\begin{array}{l}14 \\
18 \\
32\end{array}$ & $\begin{array}{l}13 \\
17 \\
31\end{array}$ \\
\hline $\begin{array}{c}\text { DG } \\
\text { size } \\
(\mathbf{k V A})\end{array}$ & - & $\begin{array}{l}1114.5 \\
123.96 \\
1034.1\end{array}$ & $\begin{array}{l}1024.3 \\
618.11 \\
967.87\end{array}$ & $\begin{array}{l}1114.5 \\
1114.5 \\
770.26\end{array}$ & $\begin{array}{l}1014.2 \\
1114.5 \\
909.6\end{array}$ & $\begin{array}{l}774.83 \\
1114.5 \\
1052.5\end{array}$ & $\begin{array}{l}679.8 \\
130.2 \\
1108.5\end{array}$ & $\begin{array}{l}757.1 \\
149.7 \\
964.8\end{array}$ \\
\hline $\begin{array}{c}\mathbf{P}_{\text {loss }} \\
(\mathbf{K W})\end{array}$ & 203 & 31.47 & 20.75 & 22.88 & 16.65 & 15.63 & 37.85 & 36.86 \\
\hline $\begin{array}{l}\mathbf{V}_{\min } \\
\text { (pu) } \\
\text { (bus) }\end{array}$ & $\begin{array}{c}0.9131 \\
(18)\end{array}$ & $\begin{array}{c}0.9810 \\
8(25)\end{array}$ & $\begin{array}{c}0.9844 \\
(18)\end{array}$ & $\begin{array}{c}0.9846 \\
1(25)\end{array}$ & $\begin{array}{c}0.9854 \\
(18)\end{array}$ & $\begin{array}{c}0.9905 \\
(33)\end{array}$ & $\begin{array}{c}0.9802 \\
(29)\end{array}$ & $\begin{array}{c}0.9792 \\
(25)\end{array}$ \\
\hline $\begin{array}{l}\text { Voltage } \\
\text { profile }\end{array}$ & 1.7012 & 0.2246 & $\begin{array}{l}0.1993 \\
5\end{array}$ & $\begin{array}{c}0.1857 \\
9\end{array}$ & $\begin{array}{c}0.1598 \\
7\end{array}$ & $\begin{array}{c}0.1603 \\
8\end{array}$ & NA & NA \\
\hline $\begin{array}{l}\text { Time } \\
\text { (sec) }\end{array}$ & & 20.2 & 19.5 & 19.7 & 18.9 & 19.7 & NA & NA \\
\hline
\end{tabular}

Table 4 Economical costs for DG allocation for 33 bus system (Type-III)

\begin{tabular}{cccccc}
\hline Method & WOA & FPA & ALO & MSA & SBO \\
\hline $\begin{array}{c}\text { Investment } \\
\text { Cost(\$) }\end{array}$ & 722667.4 & 830057.5 & 953764.5 & 966179.2 & 935488.5 \\
$\begin{array}{c}\text { Operational } \\
\text { Cost(\$) } \\
\text { Maintenance } \\
\text { Cost(\$) }\end{array}$ & 135016.6 & 155080.5 & 178192.8 & 180512.2 & 174778.2 \\
$\begin{array}{c}\text { Total costs(\$) } \\
\begin{array}{c}\text { DG Owne r's } \\
\text { Income(\$) }\end{array}\end{array}$ & 1417038 & 1627614 & 1870184 & 1894528 & 1834348 \\
\hline
\end{tabular}

\section{A.2. $\quad$ Test case2: 69- bus test system}

The second test system used is 69-bus systems with the load of $3800 \mathrm{~kW}$ and $2690 \mathrm{KVAR}$, respectively and data related to this test system is taken from [18]. Before the placement of DG units the minimum voltage is 0.90919 p.u occurred at bus 65 and total active and reactive power losses are $224.95 \mathrm{~kW}$ and 102.12 KVAR, respectively.

\section{Scenario-I:}

The performance of the optimization methods with DGs operating at unity power factor is simulated. The optimal DG sizes, locations, the total power loss, minimum voltage magnitude and voltage profile with placement of DG are given in Table 5 . The results obtained by the methods are compared with the other popular methods, i.e. GA and GA/PSO

Fig. 8 shows the convergence curve of different optimization technique considering minimization of network power losses.

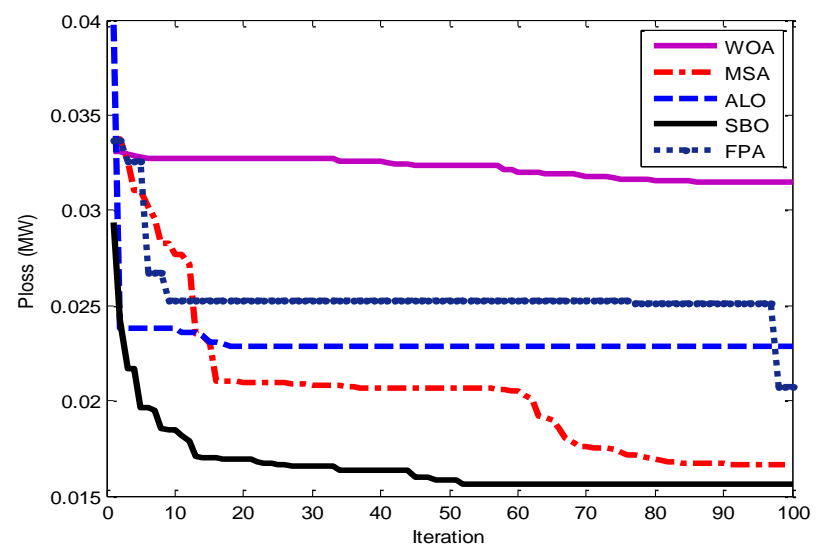

Fig.7 A convergence between the characteristics of objective function for 33-bus system (Type-III)

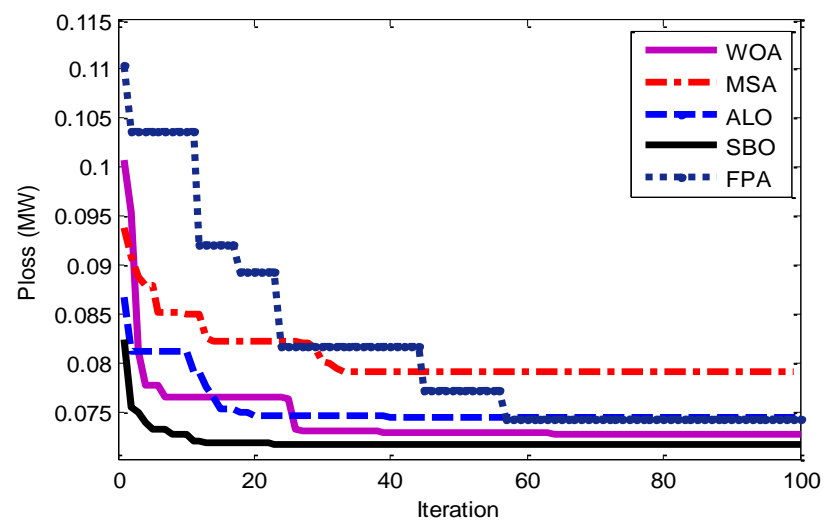

Fig. 8 A convergence between the characteristics of objective function for 69 bus system (Type I)

The Investment Cost, Operational Cost, Maintenance Cost, total costs and DG Owner's Income are shown in Table 6 for DGs operating at unity power factor.

\section{Scenario II:}

In the same manner the optimization methods with DGs operating at 0.866 power factor is simulated and obtained results are shown in Table 7.

The convergence characteristic of the power loss is shown in Fig.9 the SBO algorithm achieves the best performance, while the WOA algorithm obtains the worst one.

In Table 8 gives the investment Cost, Operational Cost, Maintenance Cost, total costs and DG Owner's Income for DGs operating at 0.866 power factor. 
Shimaa Mohamed Ali, Al-Attar Ali Mohamed, Ashraf Mohamed Hemeida, Abdalla Ahmed Ibrahim “Optimal All..."

Table 5 Comparison and performance analysis of 69-bus test system at unity power factor

\begin{tabular}{|c|c|c|c|c|c|c|c|c|}
\hline Method & $\begin{array}{l}\text { Base } \\
\text { Case }\end{array}$ & WOA & FPA & ALO & MSA & SBO & $\begin{array}{c}\text { GA } \\
{[19]}\end{array}$ & $\begin{array}{l}\text { GA/PO } \\
{[19]}\end{array}$ \\
\hline $\begin{array}{c}\text { DG } \\
\text { Location }\end{array}$ & - & $\begin{array}{l}12 \\
61 \\
64\end{array}$ & $\begin{array}{c}18 \\
63 \\
60\end{array}$ & $\begin{array}{l}61 \\
66 \\
61\end{array}$ & $\begin{array}{c}61 \\
9 \\
17\end{array}$ & $\begin{array}{l}61 \\
17 \\
61\end{array}$ & $\begin{array}{l}21 \\
62 \\
64\end{array}$ & $\begin{array}{l}63 \\
61 \\
21\end{array}$ \\
\hline $\begin{array}{c}\text { DG } \\
\text { size }(\mathbf{k W})\end{array}$ & - & $\begin{array}{l}929.57 \\
1140.6 \\
503.55\end{array}$ & $\begin{array}{l}398.04 \\
1071.5 \\
658.43\end{array}$ & $\begin{array}{l}960.61 \\
831.07 \\
771.76\end{array}$ & $\begin{array}{c}1140.6 \\
1140.6 \\
462.9\end{array}$ & $\begin{array}{l}1014.2 \\
530.47 \\
767.43\end{array}$ & $\begin{array}{c}929.7 \\
1075.2 \\
992.5\end{array}$ & $\begin{array}{l}884.9 \\
1192 . \\
6 \\
910.5\end{array}$ \\
\hline $\mathbf{P l}_{\text {oss }}(\mathrm{KW})$ & 203 & 72.65 & 74.17 & 74.48 & 79.11 & 71.67 & 89.00 & 81.10 \\
\hline$\underset{\text { (bus) }}{\mathbf{V}_{\min }(\mathbf{p u})}$ & $\begin{array}{c}0.9092 \\
(65)\end{array}$ & $\begin{array}{c}0.9794 \\
(61)\end{array}$ & $\begin{array}{c}0.9758 \\
(65)\end{array}$ & $\begin{array}{c}0.9778 \\
(27)\end{array}$ & $\begin{array}{c}0.9626 \\
(65)\end{array}$ & $\begin{array}{c}0.97893 \\
(65)\end{array}$ & $\begin{array}{c}0.996 \\
(57)\end{array}$ & $\begin{array}{l}0.992 \\
5 \\
(65)\end{array}$ \\
\hline $\begin{array}{l}\text { Voltage } \\
\text { profile }\end{array}$ & 1.8367 & 0.5477 & 0.63238 & 0.62391 & 0.59584 & 0.50012 & NA & NA \\
\hline Time(sec) & & 19.3 & 19 & 1.92 & 18.8 & 18.9 & NA & NA \\
\hline
\end{tabular}

Table 7 Comparison and performance analysis of 69 -bus system at 0.866 power factor

\begin{tabular}{|c|c|c|c|c|c|c|c|c|}
\hline Method & $\begin{array}{l}\text { Base } \\
\text { Case }\end{array}$ & WOA & FPA & ALO & MSA & SBO & $\begin{array}{r}\text { BFOA } \\
{[22]}\end{array}$ & FA \\
\hline $\begin{array}{c}\text { DG } \\
\text { Location }\end{array}$ & - & $\begin{array}{l}12 \\
61 \\
28\end{array}$ & $\begin{array}{l}52 \\
61 \\
12\end{array}$ & $\begin{array}{l}19 \\
61 \\
11\end{array}$ & $\begin{array}{l}61 \\
61 \\
68\end{array}$ & $\begin{array}{l}62 \\
17 \\
61\end{array}$ & $\begin{array}{l}61 \\
65 \\
27\end{array}$ & $\begin{array}{l}61 \\
64 \\
27\end{array}$ \\
\hline $\begin{array}{c}\text { DG } \\
\text { size }(\mathrm{kVA})\end{array}$ & - & $\begin{array}{l}693.19 \\
1520.8 \\
1112.1\end{array}$ & $\begin{array}{c}0 \\
1520.8 \\
933.21\end{array}$ & $\begin{array}{c}449 \\
1520.8 \\
522.23\end{array}$ & $\begin{array}{l}931.63 \\
889.46 \\
655.96\end{array}$ & $\begin{array}{l}613.81 \\
544.25 \\
1221.8\end{array}$ & $\begin{array}{c}1336.1 \\
328.5 \\
378.1\end{array}$ & $\begin{array}{r}1325 \\
350 \\
358\end{array}$ \\
\hline $\mathbf{P}_{\text {loss }}(\mathbf{K W})$ & $\begin{array}{r}224.8 \\
7\end{array}$ & 14.46 & 13.26 & 8.91 & 12.91 & 8.79 & 12.90 & 12.99 \\
\hline $\begin{array}{c}\mathbf{V}_{\min }(\mathbf{p . u}) \\
\text { (bus) }\end{array}$ & $\begin{array}{r}0.909 \\
(65)\end{array}$ & $\begin{array}{c}0.9838 \\
(27)\end{array}$ & $\begin{array}{c}0.9874 \\
(65)\end{array}$ & $\begin{array}{c}0.9877 \\
(65)\end{array}$ & $\begin{array}{r}0.9853 \\
3(27)\end{array}$ & $\begin{array}{l}0.99425 \\
\quad(50)\end{array}$ & $\begin{array}{c}0.9896 \\
(64)\end{array}$ & $\begin{array}{r}0.9895 \\
(68)\end{array}$ \\
\hline $\begin{array}{l}\text { Voltage } \\
\text { profile }\end{array}$ & 1.836 & 0.4268 & 0.2935 & 0.1612 & 0.2674 & 0.11916 & NA & NA \\
\hline Time (sec) & - & 29.1 & 29.3 & 28.1 & 28.2 & 26.7 & NA & NA \\
\hline
\end{tabular}

\section{A.3. Test case3: 119- bus test system}

To show the applicability of the optimization methods approach in large scale distribution network, it is applied on 119 node radial distribution network. It is a balanced three phase radial network consists of 119 nodes with $11 \mathrm{kV}$ as operating voltage level at $100 \mathrm{MVA}$ base and total real and reactive power load demands of the system are $22709.7 \mathrm{~kW}$ and 17041.1 KVAR, respectively. The initial real and reactive power loss is often compensation is $1298.1 \mathrm{~kW}$ and 978.74 KVAR, respectively. It observed that the minimum bus voltage magnitude of $0.8688 \mathrm{pu}$ is occur at node number 77 at nominal load condition [9].
Table 6 Economical costs for DG allocation for 69-bus system (Type-I)

\begin{tabular}{|c|c|c|c|c|c|}
\hline Method & WOA & FPA & ALO & MSA & SBO \\
\hline $\begin{array}{c}\text { Investment } \\
\operatorname{Cost}(\$)\end{array}$ & 818433.5 & 676697.4 & 815173.1 & 872598.8 & 735262.1 \\
\hline $\begin{array}{c}\text { Operational } \\
\operatorname{Cost}(\$)\end{array}$ & 633479.2 & 523773.4 & 630955.6 & 675403.9 & 569103.3 \\
\hline $\begin{array}{l}\text { Maintenance } \\
\operatorname{Cost}(\$)\end{array}$ & 152908.7 & 126428.1 & 152299.6 & 163028.5 & 137369.7 \\
\hline Total costs $(\$)$ & $\begin{array}{c}1604821 \\
5\end{array}$ & 1326898 & 1598428 & 1711031 & 1441735 \\
\hline $\begin{array}{l}\text { DG Owner's } \\
\text { Income(\$) }\end{array}$ & $\begin{array}{c}1092205 \\
5\end{array}$ & 903057.6 & 1087854 & 1164489 & 981212.6 \\
\hline
\end{tabular}

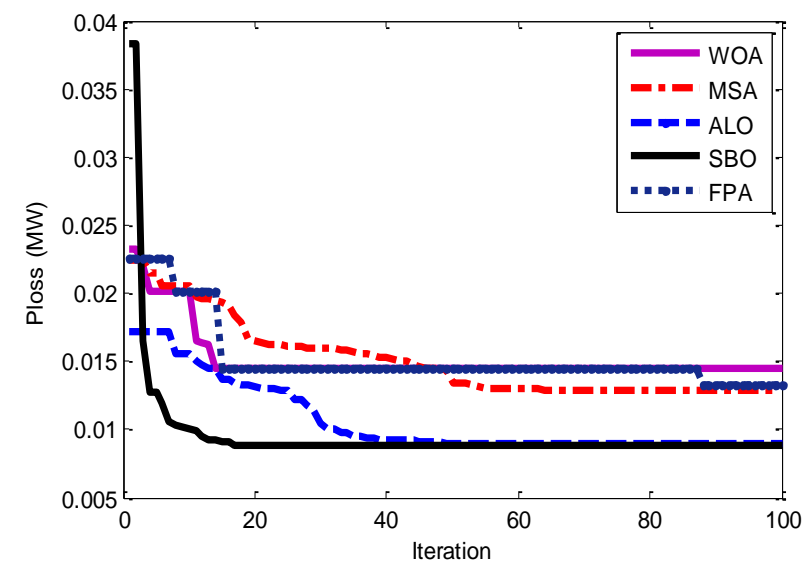

Fig.9 A convergence between the characteristics of objective function for 69bus system (Type-III)

\section{Scenario-I:}

In scenario-I, Type-I DG units capable of injecting active power only is installed at potential nodes. The optimization methods approaches simulation results are summarized in table 9. The results clearly show that optimization techniques are reduced the power losses effectively with DG compared to all other methods.

\section{Scenario-II:}

The optimization methods continuous to investigate the performance of the test system with the placement of Type-III DG units capable of injecting both real and reactive powers operating at 0.866 power factor is placed at potential nodes. The optimization methods simulation results are summarized in table 10. 
Shimaa Mohamed Ali, Al-Attar Ali Mohamed, Ashraf Mohamed Hemeida, Abdalla Ahmed Ibrahim "Optimal All..."

Table 8 Economical costs for DG allocation for 69-bus system (Type-III)

\begin{tabular}{cccccc}
\hline Method & WOA & FPA & ALO & MSA & SBO \\
\hline $\begin{array}{c}\text { Investment } \\
\text { Cost(\$) }\end{array}$ & 1057693.8 & 780361.7 & 792450.5 & 787702.85 & 756803.5 \\
$\begin{array}{c}\text { Operational } \\
\text { Cost(\$) }\end{array}$ & 818670.15 & 604011.1 & 613367.9 & 609693.23 & 585776.7 \\
$\begin{array}{c}\text { Maintenance } \\
\text { Cost(\$) }\end{array}$ & 197610.03 & 145795.7 & 148054.3 & 147167.33 & 141394.4 \\
$\begin{array}{c}\text { Total costs(\$) } \\
\text { DG Owner's }\end{array}$ & 2073974.1 & 1530168 & 1553872 & 1544563.4 & 1483974 \\
Income(\$) & 1411500.2 & 1041398 & 1057531 & 1051195.2 & 1009959 \\
\hline
\end{tabular}

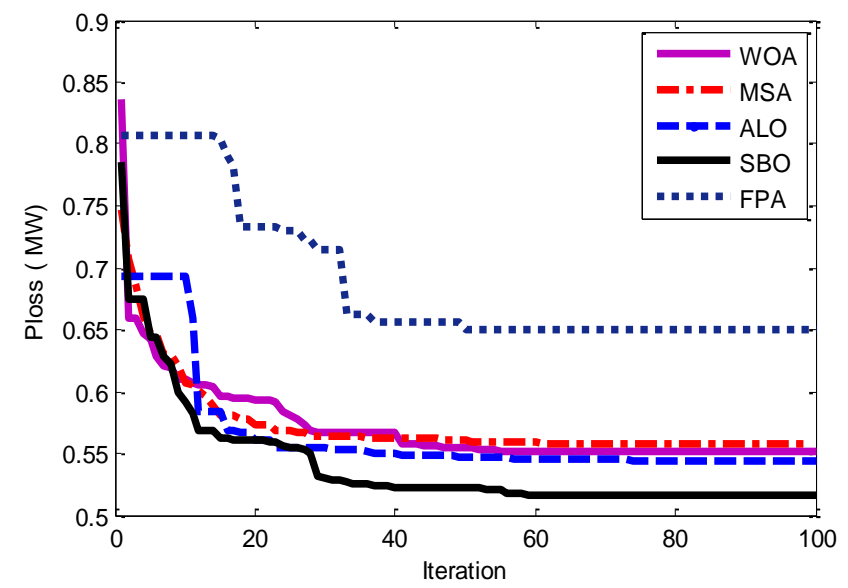

Fig.10 A convergence between the characteristics of objective function for 119bus system (Type-I)

The convergence plot of the optimization methods with scenario I and scenario-II (Test case-3) at nominal load level are depicted in Figs 10 and 11 . They observed that the optimization methods have been reduced the power losses effectively after placement of DGs.

The Investment Cost, Operational Cost, Maintenance Cost, total costs and DG Owner's Income are shown in Tables 11 and 12 for DGs operating at unity and 0.866 power factor
Table 9 Comparison and performance analysis of 119 -bus system at unity power

\begin{tabular}{|c|c|c|c|c|c|c|c|}
\hline Method & $\begin{array}{l}\text { Base } \\
\text { Case }\end{array}$ & WOA & FPA & ALO & MSA & SBO & [23] \\
\hline \multirow{7}{*}{$\begin{array}{c}\text { DG } \\
\text { Location }\end{array}$} & \multirow{7}{*}{$\operatorname{cosec}$} & 73 & 71 & 109 & 50 & 96 & 36 \\
\hline & & 79 & 28 & 36 & 109 & 41 & 48 \\
\hline & & 109 & 82 & 42 & 91 & 50 & 56 \\
\hline & & 96 & 112 & 50 & 72 & 109 & 75 \\
\hline & & 15 & 90 & 82 & 55 & 20 & 88 \\
\hline & & 29 & 53 & 73 & 42 & 72 & 103 \\
\hline & & 50 & 117 & 96 & 33 & 80 & 116 \\
\hline \multirow{7}{*}{$\begin{array}{c}\text { DG } \\
\text { size } \\
(\mathbf{k W})\end{array}$} & \multirow{7}{*}{ - } & 2096.8 & 1471.5 & 3124.3 & 1974.4 & 1668.8 & 7467.3 \\
\hline & & 2573.3 & 2176.6 & 2341 & 3118.7 & 1843.1 & 710.9 \\
\hline & & 3507.8 & 1077 & 1059.6 & 1919 & 2731 & 3673.9 \\
\hline & & 1922.7 & 2546.3 & 2853.6 & 2594.1 & 3122.3 & 2824.6 \\
\hline & & 800.3 & 2995.5 & 688.38 & 1546.3 & 1789.7 & 2297.9 \\
\hline & & 2758.7 & 2014.5 & 2459.3 & 1188.6 & 2534.3 & 5080.3 \\
\hline & & 2870.3 & 160.89 & 2257 & 1747.2 & 2097.1 & 460.6 \\
\hline $\begin{array}{c}\mathbf{P l}_{\text {oss }} \\
(\mathbf{K W})\end{array}$ & $\begin{array}{c}1298 . \\
1\end{array}$ & 551.5 & 649.55 & 544.40 & 557.94 & 516.27 & 900.188 \\
\hline $\begin{array}{l}\mathbf{V}_{\min } \\
\text { (p.u) } \\
\text { (bus) }\end{array}$ & $\begin{array}{c}0.868 \\
8 \\
(77)\end{array}$ & $\begin{array}{l}0.9527 \\
(77)\end{array}$ & $\begin{array}{l}0.9261 \\
(77)\end{array}$ & $\begin{array}{c}0.9594 \\
(54)\end{array}$ & $\begin{array}{c}0.9543 \\
(54)\end{array}$ & $\begin{array}{c}0.9544 \\
(54)\end{array}$ & NA \\
\hline $\begin{array}{l}\text { Voltage } \\
\text { profile }\end{array}$ & $\begin{array}{c}5.244 \\
9\end{array}$ & 2.3901 & 2.98522 & 2.3309 & 2.4771 & 2.2543 & NA \\
\hline $\begin{array}{l}\text { Time } \\
(\mathrm{sec})\end{array}$ & & 157 & 165 & 163 & 155 & 158 & NA \\
\hline
\end{tabular}

Table 10 Comparison and performance analysis of 119 -bus system at 0.866 power factor

\begin{tabular}{|c|c|c|c|c|c|c|c|}
\hline Method & $\begin{array}{l}\text { Base } \\
\text { Case }\end{array}$ & WOA & FPA & ALO & MSA & SBO & [23] \\
\hline $\begin{array}{c}\text { DG } \\
\text { Location }\end{array}$ & - & $\begin{array}{c}87 \\
73 \\
109 \\
48 \\
96 \\
100 \\
39\end{array}$ & $\begin{array}{c}107 \\
79 \\
118 \\
57 \\
70 \\
54 \\
6\end{array}$ & $\begin{array}{c}80 \\
110 \\
96 \\
11 \\
72 \\
42 \\
50\end{array}$ & $\begin{array}{c}42 \\
109 \\
80 \\
37 \\
50 \\
72 \\
20\end{array}$ & $\begin{array}{c}50 \\
109 \\
30 \\
96 \\
41 \\
80 \\
74\end{array}$ & $\begin{array}{c}36 \\
48 \\
56 \\
75 \\
88 \\
103 \\
116\end{array}$ \\
\hline $\begin{array}{c}\text { DG } \\
\text { size } \\
(\mathbf{k V A})\end{array}$ & - & $\begin{array}{l}2589.8 \\
2043.6 \\
4050.4 \\
1680.7 \\
1286.8 \\
4121.6 \\
2442.3\end{array}$ & $\begin{array}{c}3.922 .1 \\
3210.9 \\
119.22 \\
423.69 \\
2542.6 \\
2080.5 \\
6655\end{array}$ & $\begin{array}{c}2337.6 \\
3140.4 \\
1364.9 \\
3584.5 \\
2555.9 \\
1248 \\
3275.3\end{array}$ & $\begin{array}{c}1245.2 \\
3370.6 \\
2462.9 \\
1797 \\
2873.1 \\
2758.7 \\
2287.6\end{array}$ & $\begin{array}{c}2637.1 \\
3379.3 \\
3772.1 \\
1721 \\
1648.8 \\
2226.9 \\
2369.6\end{array}$ & $\begin{array}{l}7056.5 \\
2514.7 \\
4979.5 \\
3180.5 \\
723.10 \\
6160.5 \\
586.14\end{array}$ \\
\hline $\mathbf{P}_{\text {loss }}(\mathbf{K W})$ & $\begin{array}{c}1298 . \\
1\end{array}$ & 288.9 & 333.65 & 162.86 & 190.25 & 152.22 & 638.968 \\
\hline $\begin{array}{c}\mathbf{V}_{\min } \\
\text { (p.u.) } \\
\text { (bus) }\end{array}$ & $\begin{array}{c}0.868 \\
8 \\
(77)\end{array}$ & $\begin{array}{c}0.9485 \\
(54)\end{array}$ & $\begin{array}{c}0.96504 \\
(46)\end{array}$ & $\begin{array}{c}0.9758 \\
(62)\end{array}$ & $\begin{array}{l}0.96502 \\
(99)\end{array}$ & $\begin{array}{l}0.96946 \\
(27)\end{array}$ & NA \\
\hline $\begin{array}{l}\text { Voltage } \\
\text { profile }\end{array}$ & $\begin{array}{c}5.244 \\
9\end{array}$ & 1.7849 & 1.73176 & 0.83935 & 1.00358 & 0.87374 & NA \\
\hline $\begin{array}{l}\text { Time } \\
\text { (sec) }\end{array}$ & - & 162 & 166 & 163 & 157 & 160 & NA \\
\hline
\end{tabular}




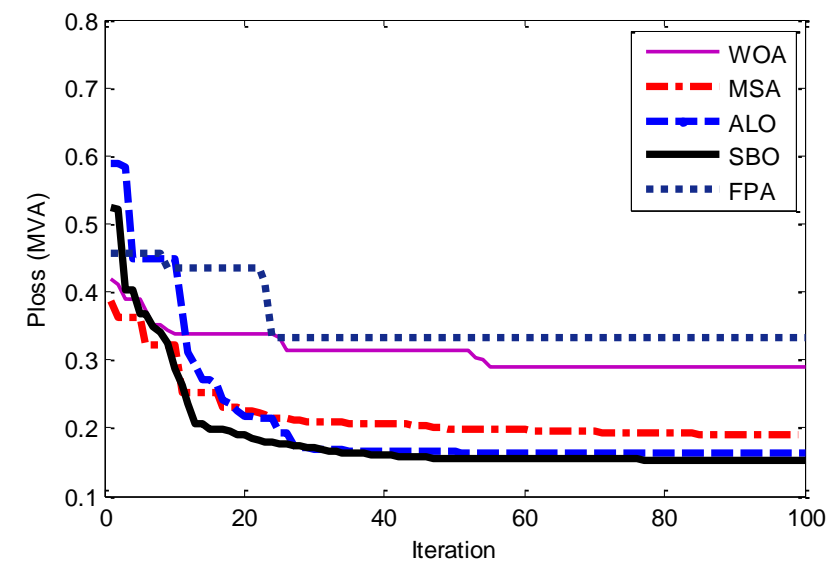

Fig.11 Convergence characteristics of objective function for 119-bus system (Type-III)

Table 11 Economical costs for DG allocation for 119-bus system (Type-I)

\begin{tabular}{cccccc}
\hline Method & WOA & FPA & ALO & MSA & SBO \\
\hline $\begin{array}{c}\text { Investment } \\
\text { Cost(\$) }\end{array}$ & 2600565 & 1502580 & 2074930 & 2229851.9 & 1985214 \\
$\begin{array}{c}\text { Operational } \\
\text { Cost(\$) } \\
\text { Maintenance } \\
\text { Cost(\$) }\end{array}$ & 2012874 & 1163018 & 1606026 & 1725937.2 & 1536584 \\
$\begin{array}{c}\text { Total costs(\$) } \\
\text { DG Owner's } \\
\text { Income(\$) }\end{array}$ & 5099306 & 29466327 & 4068618 & 4372394.7 & 3892699 \\
\hline
\end{tabular}

Table 12 Economical costs for DG allocation for 119-bus system (Type-III)

\begin{tabular}{|c|c|c|c|c|c|}
\hline Method & WOA & FPA & ALO & MSA & SBO \\
\hline $\begin{array}{c}\text { Investment } \\
\operatorname{Cost}(\$)\end{array}$ & 2761464 & 2306223 & 2176045 & 2251018.5 & 3112760.9 \\
\hline $\begin{array}{l}\text { Operational } \\
\operatorname{Cost}(\$)\end{array}$ & 2137413 & 1785050 & 1684290 & 1742320.4 & 2409321.3 \\
\hline $\begin{array}{l}\text { Maintenance } \\
\operatorname{Cost}(\$)\end{array}$ & 515927.2 & 430874 & 406552.8 & 420560.11 & 581560.32 \\
\hline Total costs (\$) & 5414805 & 4522147 & 4266888 & 4413899.1 & 6103642.6 \\
\hline $\begin{array}{c}\text { DG Owner's } \\
\text { Income(\$) }\end{array}$ & 3685194 & 3077672 & 2903948 & 3004000.7 & 4154002.3 \\
\hline
\end{tabular}

\section{Conclusion}

This paper proposes integrated approach of five optimization methods (WOA, FPA, ALO, MSA and SBO) to identify the optimal allocation of distributed generations (DGs) for RDN to accomplish the benefits of reduction in power losses along with enhancement in bus voltage profile. The optimization techniques are implemented on IEEE 33, 69 and 119-bus systems. DGs operating at different power factors have been considered that is unity and lagging power factor. The obtained results of the optimization methods have been compared with other popular methods, i.e. GA, combined GA/PSO, BFOA methods and other technical. The results clearly indicate that the optimization method reduces the power losses and the total economical costs with reduced DG sizes compared to all other classical methods. It was clearly observed that the power losses are reduced and the voltage profile is improved effectively with optimal placement of DGs at (type III) rather than (type I). but the total economical costs are increased. DG Owner's Income is increased with optimal placement of DGs at lagging power factor. The SBO algorithm achieves the best result than MSA, FBA, ALO and finally the WOA algorithm. So, it can be concluded that the optimization methods give optimal solutions in terms of reducing objective function compared to the all other classical methods.

\section{REFERENCES}

[1] A. A. El-Gaafary et al, "Grey wolf optimization for multi input multi output system", Univers. J. Commun. Network, vol. 3, no. 1, pp. 1-6, 2015.

[2] D. Singh and R. K. Misra, "Effect of load models in distributed generation planning," IEEE Trans. Power Syst., vol. 22, no. 4, pp. 2204-2212. 2007.

[3] T. Ackermann. G. Andersson. and L. Soder. "Multiple Distributed Generator Placement in Primary Distribution Networks for Loss Reduction," IEEE Trans. Power Syst, vol. 60, no. 4, 2013.

[4] M. N. Marwali. J. W. Jung. and A. Kevhani. "Stabilitv analysis of load sharing control for distributed generation systems," IEEE Trans. Energy Convers., vol. 22, no. 3, pp. 737-745, Sep. 2007.

[5] W. Li, G. Joos, and J. Belanger, "Real-time simulation of a wind turbine generator coupled with a battery supercapacitor energy storage system," IEEE Trans. Ind. Electron., vol. 57, no. 4, pp. 1137-1145, Apr. 2010.

[6] A. Pigazo, M. Liserre, R. A. Mastromauro, V. M. Moreno, and A. Dell'Aquila, "Wavelet-based islanding detection in grid-connected PV svstem" .IEEE Trans. Ind. Electron., vol. 56, no. 11, pp. 4445-4455, Nov. 2009.

[7] A. A. El-Gaafary et al., "Grey wolf optimization for multi input multi output system", Univers. J. Commun. Network, vol. 3, no. 1, pp. 1-6, 2015.

[8] A. A. Mohamed et al., "Optimal power flow using moth swarm algorithm", Electr. Power Syst. Res., vol. 142, pp. 190-206, 2017. 
[9] K. Muthukumar , S. Jayalalitha, "Optimal placement and sizing of distributed generators and shunt capacitors for power loss minimization in radial distribution networks using hybrid heuristic search optimization technique" Electrical Power and Energy Svstems .vol. 78. 299-319. (2016)

[10] Amir Ameli, Shahab Bahrami, Farid Khazaeli, etl "A Multiobiective Particle Swarm Optimization for Sizing and Placement of DGs from DG Owner's and Distribution Company's Viewpoints". IEEE Transactions on power delivery, vol. 29 , no. 4 , august 2014.

[11] K.R. Devabalaji, and K. Ravi. "Optimal size and siting of multiple DG and DSTATCOM in radial distribution system using bacterial foraging optimization algorithm." Ain Shams Engineering Journal vol.7, no.3, pD.959-971.2016.

[12] S. Mirialili, "The ant lion optimizer," Advances in Engineering Software. vol. 83. nn. 80-98. 2015.

[13] Yano XS. "Flower nollination alorithm for glohal ontimization". In: Inconventional comnutation and natural comnutation. I ecture Notes in Computer Science. vol. 7445. pD. 240-249. 2012.

[14] Yang XS, Karamanoglu M, He X, "Multi-obiective flower algorithm for optimization". Procedia Comput Sci;vol, vol, 61, pp.8-18, 2013.

[15] S. Mirialili and A. Lewis, "the whale optimization algorithm". Adv. Eng. Softw, vol. 95, pp. 51-67, May 2016.

[16] Samareh Moosavi, S. H., \& Khatibi Bardsiri, V, "Satin bowerbird optimizer". Engineering Applications of Artificial Intelligence, vol.60, pp.1-15.
[17] Al-Attar Ali Mohamed,, Yahia S. Mohamed, Ahmed A.M. El-Gaafary , Ashraf M. Hemeida, "Optimal power flow using moth swarm algorithm". Electric Power Systems Research vol.142, pp.190-20, 2017.

[18] Sahoo, N. C., \& Prasad, K.: "A fuzzy genetic approach for network reconfiguration to enhance voltage stability in radial distribution systems.": Energy Convers. Manage. Vol.47, pp 3288-3306, 2006.

[19] Moradi, M. H., and M. Abedini. "A combination of genetic algorithm and particle swarmoptimization for optimal DG location and sizing in distribution systems." Int J Electr Power Energy Syst, vol. 34, pp.66-74, 1 (2012):

[20] Mohamed Imran A. Kowsalva M." Optimal size and sitting of multiple distributed generators in distribution system using bacterial foraging optimization. Swam". Evol Comput. vol.15. pD.58-65. 2014.

[21] Sureshkumar Sudahattula. Kowsalva M. “ontimal allocation of multinle distributed generators in distribution svstem using firefly algorithm" Journal of Flectrical Fnoineering,

[22] Kowsalva. M. "Ontimal size and siting of multinle distributed generators in distribution svstem using hacterial foraging ontimization." Int. J. swarm and Evolut. Comput. pD58-65. 2013.

[23] Inieti Satish Kumar, Kumar Prema," A novel approach to identify optimal access point and capacity of multiple DGs in small, medium and large scale radial distribution systems". Int J Electr Power Energy Syst, vol .45, pp.142-51, 2013. 